Studia z Dziejów Średniowiecza, t. 24, 2020

\author{
Rafał Kubicki \\ (University of Gdańsk) \\ https://orcid.org/0000-0002-2171-5713
}

Omnia allodia et molendina, totaliter combusta sunt

\title{
Damaging, Destroying and Rebuilding of Watermills and Windmills in the Late-Medieval State of the Teutonic Order in Prussia ${ }^{1}$
}

\author{
https://doi.org/10.26881/sds.2020.24.03
}

Keywords: medieval Prussia, Teutonic Order, rural settlement, watermill, windmill

Watermills and windmills were an important infrastructural element in villages and towns of the late Middle Ages, which made it possible to grind proper volumes of grain and malt required for the production of two of the most important food products of the time: bread and beer. As such, they were vulnerable to destruction during military conflicts of the period. Obviously, damaging or destroying watermills and windmills also occurred as a result of natural causes: atmospheric factors (surging waters, broken dykes in the case of watermills, or strong winds when it comes to windmills). Many installations of that

1 The article is based partly on the results of detailed research of the milling industry in the state of the Teutonic Order, full presentation of which is offered in my book Mtynarstwo w państwie zakonu krzyżackiego w Prusach $w$ XIII-XV wieku (do 1454 r.) [The Milling Industry in the State of the Teutonic Order in Prussia in the $13^{\text {th }}-15^{\text {th }}$ Century (to 1454)], Gdańsk 2012. 
type deteriorated through ongoing wear and tear as well as a lack of proper maintenance or sometimes even a conscious abandonment of their further use because of economic changes and recession in agriculture. The issue of damaging, destroying, but also reconstructing watermills and windmills, will be presented here via the example of the dominion (Ger. Landesherrschaft) of the Teutonic Order in Prussia in the late Middle Ages (in the $14^{\text {th }}$ and the first half of the $15^{\text {th }}$ centuries). Apart from legal and economic issues connected with this phenomenon, we will attempt to define the scale and location of empty, destroyed, or only abandoned or damaged mills, which were later not rebuilt in the first half of the $15^{\text {th }}$ century.

\section{The legal status of windmills and watermills in cases of destruction}

Basic information on the subject of the rules governing the operation of windmills and watermills in the area that is the subject of my research is provided in documents issued in connection with their construction. These were received by millers or owners of milling plants and other workshops running on hydropower (such as lumber mills, weaving mills, forges, or polishing shops). This was so because the Teutonic Order in their dominion in Prussia, and also after 1308 in Eastern Pomerania, had all the water rights at their disposal and almost complete control of the process of location of towns and villages, including the right to build watermills for their needs. Similar regulations were also later applied in the case of windmills ${ }^{2}$. The content of the so-called Kulm privilege issued in 1233 (a document with the same regulation concerning watermills was reissued in 1251) during the location of the first towns of Chełmno (Ger. Kulm) and Torun (Ger. Thorn), reads that the owner of a field which was aligned to a river had the right to build one water mill in its vicinity. The following clause turned out to be crucial: "However, if the same river was fit to have many mills [built], our Order shall give a third of the costs incurred in building

2 G. Kisch, Das Mühlenrecht im Deutschordensgebiete [in:] idem, Studien zur Rechts- und Sozialgeschichte des Deutschordenslandes, Sigmaringen 1973, pp. 87-164. 
others and it shall forever levy a third of the income from those"3. In practice, this meant that the construction of watermills along all suitable larger watercourses was to be undertaken under the supervision of the Teutonic Order ${ }^{4}$. Later in practice, the Order, similarly to bishops and cathedral chapters in their own lands, had the exclusive right to decide about building watermills, which derived not only from their economic but also military importance, according to Guido Kisch ${ }^{5}$. The possibility of building a watermill, later also a windmill, was then dependent each time on the acceptance of the Teutonic Order, the bishop, or the chapter. Those institutions gave their consent and approval by issuing a proper document, which will, thus, be called a "milling privilege" 6 . Those documents provide an abundance of information about the rules that applied to the development and use of mills ${ }^{7}$. Apart from such privileges, similar information is contained in their contracts of sales. In total, in Prussia and Eastern Pomerania, in various forms (original documents, transcripts), information on regulations upon which circa 240 mills were used have survived, including over 180 milling privileges and 40 documents of their sales. Nearly a 100 of them were issued by Teutonic Order officials (the Grand Master, the Grand

3 "Item si rivus aliquis agros alicuius civis attigerit, ei, cuius agri fuerint, solum molendinum edificare liceat in eodem. Si vero idem fluvius aptus fuerit pluribus molendinis, domus nostra in construendis eisdem aliis terciam partem priorum sumptuum faciat et participet perpetualiter terciam partem usuum de constructis”, PrUB, Bd. I/1, no. 252, p. 188.

4 The problem with interpretation of the meaning of this article from the Kulm privilege spurred discussion in literature - see: G. Kisch, Das Mühlenregal im Deutsch-Ordensgebiete, "Zeitschrift der Savigny-Stiftung für Rechtsgeschichte. Germanische Abtheilung" 1928, Bd. 48, pp. 176-193; a polemical stance as regards decisions can be found in A. Semrau, Zur Geschichte des Mühlenregals im Deutschordenslande, "Mitteilungen des: Coppernicus-Vereins für Wissenschaft und Kunst in Thorn" (hereafter: MCV) 1929, Bd. 37, pp. 1-10. The whole discussion is recounted by G. Kisch, Das Mühlenrecht..., pp. 104-110.

5 G. Kisch, Das Mühlenrecht..., p. 103. For more detail on the subject of the military importance of mills, see: R. Kubicki, Zur militärischen Bedeutung der Wassermühlen im Ordensland Preußen [in:] Beiträge zur Militärgeschichte des Preußenlandes, hrsg. v. B. Jähnig, Berlin 2010, pp. 103-119.

6 G. Kisch, Das Mühlenrecht..., pp. 123-125, 133-135.

7 H. Steffen, Die ländliche Mühlwesen im Deutsche Ordenslande, "Zeitschrift des WestpreuBischen Geschichtsvereins” 1918, H. 58, p. 75; G. Kisch, Das Mühlenrecht..., pp. 126-127. 
Marshall, or individual commanders), whereas 65 of them were issued by bishops or chapters in Prussia ${ }^{8}$.

The content of some of those documents, apart from stipulating the general rental obligations of millers, would also sometimes contain detailed provisions specifying forms of collateral in the event of a mill being destroyed through warfare or force majeure ${ }^{9}$. This applied mainly to objects located in regions at risk because of military operations. The oldest instance of such regulations is provided in a document referring to a mill on the river Drwęca (Ger. Drewenz) in Lubicz (Ger. Leibitsch). In a document from 1292, it was determined that if the mill were to be destroyed by means of warfare "by pagans or in any similar case", the miller would be exempt from paying the rent ${ }^{10}$. The aforementioned pagans were of course Prussians, although later on the mill was also at risk because of its proximity to the Polish borders ${ }^{11}$. Similar regulations were written in the case of a mill in Kalk, located in Sambia and, thus, in danger of military conflict. In a document issued in 1357 by the bishop of Sambia, a clause was added which gave guarantees to the miller and read that if the mill were ever to be raided by "Lithuanians or any other enemies of Christianity", then the bishop would exempt the miller from paying rent for a period of one year ${ }^{12}$. Similar regulations insuring the miller directly against the results of war are infrequent in milling privileges. However, regulations protecting millers against natural disasters or random events are more frequent in such documents ${ }^{13}$. They usually referred

8 R. Kubicki, Mtynarstwo..., p. 28.

9 H. Steffen, Die ländliche Mühlwesen..., p. 80; G. Kisch, Das Mühlenrecht..., p. 137; R. Kubicki, Mtynarstwo..., p. 67-69.

10 "Porro si sepedicto molendinum per paganos aut [quovis fortassis eventu destructum fuerit, extunc predictum cen] sum nob[is solvere non tenen]tur”, PrUB, Bd. I/2, no. 592 , p. 370.

11 K. Neitmann, Der Grenzstreit zwischen dem Deutschen Orden und Polen um die Mühle von Leibitsch und die Drewenz, "Beiträge zur Geschichte WestpreuBens" 1987, Bd. 10, pp. 111-137.

12 "et si, quod deus per suam misericordiam avertat sepe dictum molendinum per Lytwanos sive alios adversarios christiane fidei devastaretur, tunc illo solo anno ex parte census liberi residerent”, UBS, no. 452, p. 305; P. Siegmund, Deutsche Siedlungstätigkeit der samländischen Bischöfe und Domkapitel vornehmlich im 14. Jahrhundert, „Altpreußische Forschungen” 1928, 5, H. 2, p. 298. The same arrangements were repeated in the new privilege for the mill and inn in Kalk from 1427, GSPK, XX. HA, Perg. Urk., Sch. XXIX no. 63.

13 R. Kubicki, Mtynarstwo..., p. 69. 
to the obligation of the person issuing the privilege to participate in the cost of renovation of mills destroyed as a result of various random incidents (natural disasters). For instance, Dieterich Czecher when appointing Hannus Segilkowen a reeve and giving him a third of the mill in the village of Próle (Ger. Prohlen) in 1372, confirmed that in the case of the mill's destruction, he would cover proportionately two thirds of the costs of rebuilding the mill (moele) and the dyke (temmen $)^{14}$. Similar confirmation from the bishop of Warmia (Ger. Ermland) was received by the reeve of Szynowo (Ger. Schönau) in 1381, who had the right to a third of the mill there $^{15}$. Analogical provisions were also included in the privilege for mills located in the dominion of the bishopric of Warmia in Ruda (Ger. Eisenwerk) (1403) ${ }^{16}$.

\section{Reasons for the destruction of watermills and windmills}

The reasons why mills were destroyed were either linked to damage inflicted to their construction (the dyke or the ditch) or deliberate actions during time of war ${ }^{17}$. Information referring to the miller's situation in the event of damage to his mill was often included in the content of the privilege or also in written bills of sales of such an installation ${ }^{18}$. Let the document referring to the mill in the village of Kabiny (Ger. Kabienen) in Warmia serve as an example here. In 1375, Johan von Czul, the mayor of the Bishop of Warmia, sold such an installation to one Heinrich, with guarantees of aid in case of its destruction ${ }^{19}$. Similarly, the Pomesanian chapter, when selling the mill (1396) in Tymawa Wielka (Ger. Thiemau), guaranteed the miller Nicolaus that in the event of the mill's destruction by fire or other misfortune caused by water, the chapter would aid in transportation of timber required for its renovation and send a carpenter and cover the cost of his work.

14 "wen die moele usbricht ader bowfellig wirt, so sal ich die czwey teile buwen und temmen und der schulcze das dritte teil", CDW, Bd. 2, no. 464, p. 469.

15 CDW, Bd. 3, no. 113, p. 85.

16 Ibidem, Bd. 3 no. 385, pp. 374-378.

17 R. Kubicki, Zur militärischen Bedeutung..., pp. 106-108, 117-119.

18 R. Kubicki, Mtynarstwo..., p. 67-69.

19 CDW, Bd. 2, no. 506, p. 543. 
In the latter case, the miller himself had only to provide wood and pay for it. Moreover, the chapter guaranteed the help of its men in cleaning and maintaining mill ditche ${ }^{20}$. Instances of mills being destroyed by fires were not so rare, which is proven by reasons given in connection with issuing renewed milling privileges. For such reasons, the following milling privileges were reissued, among others: in Samolubie (Ger. Lauterhagen) (1345), Stabunity (Ger. Stabunken) (1380) and Wadag (Ger. Wadang) (1421) in Warmia, as well as in Młynki (Ger. Alt Mühlbach) in the bishopric of Pomesania (1430) ${ }^{21}$.

In contrast, clauses referring to aid provided in cases of mills being damaged by water can only be found in several privileges. This may result from the intent the issuer of the document to provide the miller with a particular guarantee. On the other hand, proper functioning of mills influenced the situation of nearby farmsteads. Proper maintenance of dykes and ditches decreased the chance of flooding and, as a result, damage inflicted to the homesteads of villagers. Let us refer to a few regulations of that sort. In 1403, the Benedictine nuns from Torun (Ger. Thorn) sold a mill located on the river Struga Rychnowska (Ger. Lanke) and obliged their peasants in Zelgno to work on behalf of the mill if its dyke was damaged $^{22}$. In the 1412 privilege for a mill in Stary Targ (Ger. Altmark), it was established that in the event of damage to the dyke, all the peasants in the village were supposed to aid the miller in its restoration ${ }^{23}$. Similarly, in the 1413 milling privilege in Nowy Młyn (Ger. Simonsmühle) near Dzierzgon (Ger. Christburg), the

20 "Ouch were is das dy mol vorbrente adir andir schade geschege von wassers halben das sie wedir muste gebuwet werden, so solle wir jm das czymmer helfen furen vnde sunderlichen dan grosse vnd das schwesrte Adir das czymmer sal er selber schicken vnde beczalen. Ouch sullen die lute dy do malen helfen die graben suberen vnde rumen”, UBP, no. 107, p. 157.

21 G. Kisch, Das Mühlenrecht..., p. 127.

22 "Vnd were es sache, das gott nicht welde, das der tham an der Moel ausbreche, so sollen vnd mussen vnser lewten vnd vndersasse des dorffs Seglein vorgesprochenen Thoma sin vnd seinen erben vnd nochkomelungen eynen gantzen tag helfen scharwerken vnd arbeiten den tham weder zu machen vnd das wasser zu phoen bey irer kost also dicke also das nott thun wirdt; das wir auch den selben vnsern lewten ernstlichen gebytten vnd befelen also zu halten”, UBCulm, Bd. 1-2, Danzig 1885-1887, no. 443, pp. 351-352.

23 "were is sache, das das wasser als oberheren wurde und machtig, das is den tam durch ader usbrechen, szo welle wir, das die genczse gemeyner das dorff czu gee und dem molner den tam wieder helfen stowen”, GSPK, XX. HA, OF 100, 
Teutonic Order guaranteed to the owner the aid of its serfs in maintaining the dyke and the ditch of the mill ${ }^{24}$. In 1416, the chapter of Kulm, in the privilege issued for a mill located outside Nowe Miasto (Lubawskie) (Ger. Neumark), committed itself to provide aid from its peasants in order to maintain the mill dyke and conduct repairs if it were damaged through events independent of the miller's operations ( $o b$ der tam von finden adir von himelflutte verterbit wurde $)^{25}$. Yet, if the damage occurred as a result of the miller's negligence, he was to restore it on his own ${ }^{26}$. In 1433 , Carthusians guaranteed to the miller in Gołubie (Ger. Gollubien) in Eastern Pomerania the right to acquire soil needed to maintain the dyke without hindrance from the local peasants ${ }^{27}$. Some even more detailed provisions were included by the Carthusians in the milling privilege in Osłonino (Ger. Oslanin) (1434). They obliged the mill owner to tend to the dyke and to mend smaller damage in person or by other authorised persons ${ }^{28}$. However, as far as canal maintenance was concerned, the monastery was to provide aid in the form of timber and wagons. Their people were also supposed to help with transporting wood, removing and imbedding poles, while the mill owner was to cover the cost of feeding and maintaining the workers ${ }^{29}$. Similar clauses were included by the brothers Jeszke, Petrasch, Swantke, Mattis, and Rudiger from Goręczyno (Ger. Gorrenschin) in 1436, with regard to a mill located on the river Radunia (Ger. Radaune), which they sold to Martin Witten and his successors in return for a rent of 4 Chełmno marks (units of silver), free milling access for their own needs, and some eels. In the document, it was also established that in the event of the dyke breaking, they would aid in its renovation by sending their

f. $132 \mathrm{v}$. This regulation was repeated in the next privilege from 1443. (GSPK, XX. HA, OBA no. 8393).

24 "so sulle wir im den tam und den molgraben halden und bessern mit unsern luthen, wen des not ist", GSPK, XX. HA, OF 100, f. 133v.

25 "Ouch entheisse wir ym den tam czu halden vnd czu temmen mit unsern luthen. Ouch ob der tam von finden adir von himelflutte verterbit wurde, so sullen wir yn mit unsern luthen weder temmen”, UBC no. 498, p. 405.

26 "Were adir, das der tam von des molners versomunusse wurde vorwarloset, so sall yn der molner selber weder temmen", ibidem.

27 ADP, Monastica, Kartuzy, no. 5, document no. 63, p. 244.

28 P. Czaplewski, Kartuzja kaszubska, Gdańsk 1966, p. 191.

29 ADP, Monastica, Kartuzy no. 5, document no. 64, pp. 244-245. 
own men, whereas the mill user was obliged to cover the cost of food and drink for them ${ }^{30}$.

It can clearly be seen in the aforementioned examples that the attention was focused mainly on the state of dykes, which were among the sensitive elements of the whole design of the mill. Therefore, it is no wonder that in a new privilege for a mill in Zwierzynek (Ger. Hirsemühl) in 1439, the Voigt of Dirschau (Pol. Tczew) guaranteed to help in the event of damage being done to the dyke, while at the same time it obliged the miller to ensure its constant maintenance ${ }^{31}$. The promise of help in rebuilding the dyke was also included in the content of a reissued privilege for the aforementioned mill in Stary Targ (Ger. Altmark) around 1443. In the event of damage to the dyke, all the inhabitants of the village were supposed to provide aid to the miller in its restoration and in banking up water ${ }^{32}$. Similarly, in the privilege for a mill in Pokirren in Königsberg commandery from 1459, the Grand Master of the Teutonic Order undertook the obligation of the Order to restore and repair the mill dyke in the event of its damage or complete destruction $^{33}$. Including such clauses in privileges and mill sale documents was most probably dictated by a desire to provide them with additional guarantees, especially in the event of force majeure when mills were destroyed by water. Let us add that such instances were recounted in chronicles. The information recorded by the chronicle of the Pomesanian judicial vicar under the year 1388 seems to have gained particular notoriety. At that time, three days before St. Margaret's Day (July 10), because of extensive rainfall in the commanderies of Brodnica (Ger. Strasburg), Radzyń (Ger. Rehden), Rogóźno (Ger. Roggenhausen), and Pokrzywno (Ger. Engelsburg), numerous mills were damaged, including those

30 "Ob der tham ussbroche von wassirsnoth, zo wel en helffen noch unserm vormogen mit sampt unsern leuthen den tham widder bessern, so sullen sie den helffern essen und trincken geben noch yrem vormogen", ADP, Monastica, Kartuzy no. 5, document no. 73 , pp. 253-254.

31 "sonderlich ab der thamm bey der mohle ussbruche, den sollen wir ihm halffen machen, doch soll er mit vleiss darczu sehen, das es nicht gescheche", GSPK, XX. HA, OF 98, f. 119r-120r.

32 GSPK, XX. HA, OBA no. 8393 = GSPK, OBA no. 8210.

33 "weres ouch sache, das der mole tham gebrechlich wurde adir gantcz awssbrechen, so sullen und wellen wir adir em marschalk ein seinen rechten erben und nachkomen mit unseren lewten den tham widder helfen bessern addir widder gantcz helfen machen”, GSPK, XX. HA, OF 94, p. 357-359, no. 139. 
in Słup (Słupski Młyn/Ger. Mühle Slupp) and before the castle in Brodnica/Ger. Strasburg, among others ${ }^{34}$. In 1416, in another case, the mill in Brodnica/Ger. Strasburg could not work because of the breaking of the lake ${ }^{35}$. One of the reactions of the authorities to such cases was also to lower the rent paid by the miller. In 1425, Johann the Bishop of Sambia issued a document concerning the mill in Gross Hubenicken (Rus. Sinjawino), partially exempting the miller Tomas Blumenaw from paying rent for the period of two years, because of damages caused to the mill by banked up water. During that period the rent was to equal one vierdung ${ }^{36}$ (a fourth of mark).

Damages caused by force majeure (elemental forces) applied to windmills as well ${ }^{37}$. Their structure was vulnerable both to being burnt down during warfare and to atmospheric factors. In the privilege for a mill ${ }^{38}$ in Mikoszewo (Ger. Nickelswalde) (1437), the Teutonic Order promised the miller that in the event of repairs to or restoration of the mill he would have the right to acquire timber from forests belonging to the Order; yet if he were unable to acquire it there, the miller would have to buy it at his own expense ${ }^{39}$. Detailed

34 "Gros schaden geschach von irgysunge der wasser. Item dry tage vor margarethe was so gros reyn im lande czu Pruszin, das desin gebitegern: Strasburg, Redin, Roghusen, Engelsberg, ere molen usbrochin und geschsch gros schade, das des kompthurs gemach von Grudencz nedir vil in die Wysel. Und czu Fredecke vylen czwene torme neder in deme vorborge, und die mole czu Starkinberg, und die mole vor dem huse brochin ouch us, und ouch schach schade an deme huse Roghusin”, Franciscani Thorunensis Annales Prussici, hrsg. v. E. Strehlke [in:] SRP, Bd. 3, pp. 152-153; H. Plehn, Ortsgeschichte des Kreises Strasburg in Westpreussen, Königsberg 1900, p. 87.

35 Franciscani Thorunensis Annales Prussici..., p. 361-362; H. Plehn, Ortsgeschichte..., p. 87.

36 GSPK, XX. HA, OF 103, f. 16r.

37 R. Kubicki, Mtynarstwo..., p. 68; R. Kubicki, Windmills in the Dominion of the Teutonic Order in Prussia in the $14^{\text {th }}$ and the First Half of the $15^{\text {th }}$ Centuries [in:] Origines et mutationes. Transfer - Exchange - Power, eds. A. Girsztowt, P. Kitowski, A. Gierszewski, Kraków 2017, p. 224-225.

38 A windmill was mentioned there circa 1400: Das Zinsbuch des Hauses Marienburg, hrsg. v. W. Ziesemer, Marienburg 1910, p. 39. In the 1437 document a mill is also mentioned.

39 "kamphalcz und sust an anderen bawholcze, das eyne czur selben mole mochte dienen gebracht haben wurden, so sullen się das halcz, das en dorczu nutcze wirt seyn, in des egedachte fischmeisters welden und heyden, wo sie das gehaben mogen, frey und ungehindert hauen und furen mogen, sie aber sulch buwholcz in des fischmeisters welde und heyden nicht gehaben noch bekommen, so sullne 
regulations on the subject were also included in the privilege for two windmills at Radzyń Chełmiński (Ger. Rehden) from 1449. It was written there that in the event of damage inflicted during warfare or caused by a fire (krigeshowen verstoret adir fewers wegen verbrannt), which resulted in destruction of the mechanisms or the millstone, the commander in Radzyń (Ger. Rehden) was supposed to provide aid and cover half of the costs of windmill renovation. However, in the event of the windmill being damaged by a storm or strong wind (van stormes adir windes), the commander was to cover half of the cost of restoration, excluding the costs of restoration of the mechanisms and providing a new millstone ${ }^{40}$.

Still, it seems that damages inflicted by force majeure occurred more rarely that the planned destruction of mills and windmills during military operations. This was manifested, among other events, by the deliberate damaging of the windmills in Żuławy (Ger. Werder) in 1410 by the Tatar and Lithuanian forces supporting the army of King Władysław II Jagiełło ${ }^{41}$. Detailed data on sustained damages was later included in a ledger of damage from the period of the so-called "famine war" (1414) ${ }^{42}$, which remains lost. It is only from excerpts from the ledger, partially recounted in the literature, that we know of numerous water mills destroyed at that time in the land of Chełmno (Ger. Kulmerland) ${ }^{43}$. In the commandery of Kowalewo (Ger. Schönsee), eleven mills were destroyed, which would have paid

sie es umb ere egene gelt selbist kouffen und czewgen und die mole buwen bessirn", GSPK, XX. HA, OF 97, f. 50v-51r.

40 "Gescheches ouch, das Got abewende, das die windmolen krigeshowen verstoret adir fewers wegen verbrannt und die steyne und ysenwerk davon wekg komen wurden, so solle eyn kompthur czum Reden semliche windmolen die helfte bauwen und ouch steyne und ysenwerke die helfte beczalen, sundir wurden semlich windmolen van stormes adir windes wegen niderfallen und czunichte werden, so solle eyn kompthur czum Reden die helffte des buwes davon vsrichten, sundir steyne adir ysenwerk bedurffe her nicht beczalen“, GSPK, XX. HA, OF 97, f. 209v; D. Brauns, Geschichte des Culmerlandes bis zum Thorner Frieden, Thorn 1881, pp. 92-93.

${ }^{41}$ R. Kubicki, Wiatraki na Żuławach w pierwszej połowie XV w., "Roczniki Dziejów Społecznych i Gospodarczych” 2012, t. 72, p. 54.

42 Only fragments of information from damage ledgers, mainly on the topic of destroyed churches, were published by C. Krollmann, Die Bau- und Kunstdenkmäler des Ordenslandes Preussen in den Schadenbüchern (1411/19), Berlin 1919. Unfortunately, apart from several exceptions, he left out references to mills.

43 They were milling devices in settlements, villages, and towns: Tannen Mühle, Sumin (Ger. Semen), Gołębiewko (Ger. Taubendorf), Świecie nad Osą (Ger. Schwetz), Nowy Młyn (Ger. Adlig Neumühl), Chełmoniec (Ger. Chulschau), Golub (Ger. Gollub), Lisewo (Ger. Lissau), Leśno (Ger. Leszno Mühle), Radoszki 
40 lasts altogether; the losses in buildings and stone were estimated at 1,200 Chełmno marks. In the estates of the chapter of Chełmża (Ger. Kulmsee) three mills worth 1,800 florins were destroyed, and in the commandery of Thorn the losses in villages and mills equalled in total 4,000 Chełmno marks ${ }^{44}$. Outside the land of Kulm, as a result of military operations conducted at that time, numerous mills were destroyed in the commandery of Ostróda (Ger. Osterode $)^{45}$ and three mills in the commandery of Dzierzgon (Ger. Christburg) ${ }^{46}$. Also, the destruction of two mills (an upper one and a lower one) at the castle in Olsztynek (Ger. Hohenstein) ${ }^{47}$ was noted. As a result of military operations, the network of mills in Warmia also suffered huge losses. In the ledger of damage it was noted that all the mills were destroyed in the tithe collector districts of Pieniężno (Ger. Mehlsack), Olsztyn (Ger. Allenstein), Barczewo (Ger. Wartenburg), Jeziorany (Ger. Seeburg), and Biskupiec (Ger. Bischofsburg). Only two mills were left unharmed in the tithe collector district of Lidzbark (Ger. Heilsberg), with one mill undamaged in the districts of Orneta (Ger. Wormditt) and Dobre Miasto (Ger. Guttstadt) each ${ }^{48}$.

(Ger. Radosk). Add to this two windmills in front of Wąbrzeźno (Ger. Briesen) and two mills on the river Wierdzelewa (commandry of Nieszawa/Ger. Nessau).

44 Transcripts from the damage ledger for the land of Kulm, also including mills, were published by D. Brauns, Geschichte des Culmerlandes..., pp. 146, 147, 152, 155-157, 161-163.

45 Domkowo (Ger. Domkau), Samin (Ger. Seemen), Iseg, Drwęck (Ger. Dröbnitz) - see K. Abe, Die Komturei Osterode des deutschen Orden in Preußen 1341-1525, Köln-Berlin 1972 (Studien zur Geschichte Preußens, Bd. 16), pp. 87-88, 90.

46 Including Stanówko (Ger. Klein Stanau) and Stare Dolno (Ger. Alt Dollstädt) - see A. Semrau, Die Siedlungen im Kammeramt Morein (Komturei Christburg) während der Ordenszeit, MCV 1931, Bd. 39, p. 33.

47 G. Michels, Zur Wirtschaftsentwicklung von Kleinstädten und Flecken im Ordensland und Herzogtum Preussen (bis 1619) Gilgenburg - Hohenstein - Neidenburg - Ortelsburg - Willenberg, Lüneburg 1996, p. 94.

48 In cameratu Melsag (Pieniężno): "omens ville et omnia molendina et allodia”, in cameratu Allenstein (Olsztyn): "et omnia allodia et molendina, totaliter combusta sunt [...]", in cameratu Heilsberg (Lidzbark): "omnes ville et curie, omnia molendina preter duo, et omnia allodia totaliter combusta et destructa sunt [...]", in cameratu Wormedith (Orneta): "omens ville et curie, omnia allodia et omnia molendina preter unum [...]", in cameratu Gutenstadt (Dobre Miasto): “omnes ville et curie et allodia, et omnia molendina preter unum [...]", in cameratu Warthenberg (Barczewo): "et omnes ville et curie et omnia molendina et allodia totaliter destructa et combusta sunt [...]", in cameratu Seeburg (Jeziorany): "omnia molendina et allodia totaliter combusta sunt [...]", in cameratu Bisschofstein (Biskupiec): "omnes ville et molendina et omnia alvearia episcopi [...] totaliter destructa”, CDW, Bd. 3, no. 495 , pp. $504-506$. 
No mills were damaged only in the tithe collector district of Reszel (Ger. Rössel). Even when taking into consideration the possibility of some sort of overestimation of losses in the reports, such a scale of damages was still huge and referred to the vast majority of milling plants that had previously existed. When comparing the information on the number of mills in individual tithe collector districts and the scale of damage noted in the ledger, it may be assumed that they must have affected over sixty of them, that is, two thirds of all the mills operating in the area administered by the bishop or the chapter 49. Apparently, destruction of mills by armies fighting on all sides occurred later as well. During the Hussite raid in Eastern Pomerania in 1433, a mill in Zwierzynek (Ger. Hirsemühl) in the Vogtei of Dirschau (Pol. Tczew) was destroyed, among others, and was not rebuilt until $1439^{50}$.

\section{Restoration of water mills and windmills (costs, materials)}

As was mentioned above, the restoration of mills required support from the local population, supplying required materials, and providing a workforce ${ }^{51}$. Alongside professionals (workmasters werkmeister), the aid of local peasants was also required. The scale of expenses can be indirectly validated by the estimated total sums which resulted from the destruction of mills during war. In 1414, in the damage ledger of the town of Młynary (Ger. Mühlhausen), a mill belonging to the Teutonic Order appears, the value of which was estimated at 650 Chełmno marks ${ }^{52}$, whereas in the tithe collector district of Dabrówno (Ger. Gilgenburg), constituting a part of the commandery of Ostróda (Ger. Osterode), the losses caused by the destruction of mills was estimated at 30 Chełmno marks in Domkowo (Ger. Domkau), 200 Chełmno marks in the estates of Samin (Ger. Seemen), and 100 Chełmno marks in the estates of $I_{s e g^{53}}$. The

49 R. Kubicki, Mtynarstwo w państwie zakonu..., pp. 70-71.

50 "die muele zu Girssgrim im Dyrschau gebiet gelegen mit 2 rader zubawen, die in dem negsvorgangen kriegen von den feiden ist verbrandt", GSPK, XX. HA, OF 98, f. 119r-120r.

51 R. Kubicki, Mtynarstwo..., p. 68.

52 C. Krollmann, Die Bau- und Kunstdenkmäler..., p. 30.

${ }^{53}$ K. Abe, Die Komturei Osterode..., pp. 87-88. 
expenses were particularly high in cases of rebuilding mills that belonged to the Teutonic Order. We have a sheet with the precise costs of constructing a water mill in Słup (Słupski Młyn/Ger. Mühle Slupp), which in 1398 was 444 Chełmno marks in total ${ }^{54}$. The cost of the workforce was estimated at over $43 \%$ of the total sum of expenses in the case of that investment ${ }^{55}$. Even larger costs were borne while building a mill in Tczew (Ger. Dirschau). In the year 1400, nearly 1,186 Chełmno marks was spent on its construction. The mill belonged among the biggest plants of that kind in all of the dominion of the Teutonic Order, as at one point it had even operated 9 water wheels ${ }^{56}$. The mill was probably destroyed by the Hussites in 1433; yet the Order began its rebuilding soon after, under the supervision of workmaster (werkmeister) Hoegelyn ${ }^{57}$. Exorbitant costs were also borne in connection with the rebuilding process of the Order's mill in Działdowo (Ger. Soldau) in 1407. According to the calculations of the commander of Ostróda (Ger. Osterode), they were estimated at as much as 750 Chełmno marks ${ }^{58}$.

Smaller mills were rebuilt by millers themselves. In 1341, Johann the Bishop of Sambia gave to a miller called Albert a mill next to Bludau (Rus. Kostrovo), which the latter had previously rebuilt at his own expense ${ }^{59}$. Sometimes the cost of restoration would be transferred entirely onto the user, exempting him from rent in return. The Teutonic Order did so in 1445, when a site where there had been a mill in Skowarnki (Ger. Schönwerder) in the commandery of Człuchów (Ger. Schlochau), destroyed in the preceding war, was given to one Lorenz from Skowarnki. After restoring it, the man could use it without paying rent; yet after his

54 L. Weber, Preussen von 500 Jahren culturhistorischer, statistischer und militarischer Beziehung nebst Special-Geographie, Danzig 1878, pp. 228-229; Das Marienburger Tresslerbuch der Jahre 1399-1409, hrsg. v. E. Joachim, Königsberg 1896 (hereafter: MT), p. 11; J. Sarnowsky, Die Wirtschaftsführung des Deutschen Ordens in Preußen (1382-1454), Köln-Wien 1993, p. 156.

$55 \quad$ R. Kubicki, Mtynarstwo..., p. 168.

$56 \quad$ MT, pp. 48-49 see W. Długokęcki, Życie gospodarcze $i$ społeczne w XIV i pierwszej połowie XV wieku [in:] Historia Tczewa, ed. W. Długokęcki, Tczew 1998, p. 50, he calculated the sum on almost 1100 Chełmno marks.

57 GSPK, XX. HA, OBA 6693; W. Długokęcki, Życie gospodarcze $i$ społeczne..., p. 50.

58 "item die mole czu Soldaw czu buwen haben wir usgegeben 750 m", Das grosse Ämterbuch des Deutschen Ordens, hrsg. v. W. Ziesemer, Danzig 1921, p. 324.

59 "verschreibt dem Mueller Albert eine Wassermuehle mit zwei Gaengen bei dem preussischen Dorfe Bludau (Blodow), welche dieser auf eigne Kosten neu zu erbauen hat", UBS no. 317, p. 237. 
death the mill was to return to the Teutonic Order ${ }^{60}$. The problem of rebuilding watermills after war damage was connected with the desolation of villages, with a general crisis of the rural economy, and, thus, with decreasing demand for water mills. For that reason, another form of supporting the miller was to lower the rent ${ }^{61}$. For example, in 1430 Johann the Bishop of Pomesania issued a new privilege for a mill in Młynki (Ger. Alt Mühlbach), highlighting that because of war damage inflicted upon the country, the rent was estimated at 1.5 lasts (circa 4,950 litres) of grain a year, and after an expected economic restoration it was to equal the original sum of 3 lasts $^{62}$. Therefore, the rent was lowered by half during a period of economic crisis.

\section{Abandoned (empty) watermills and windmills}

Noting down empty mills which did not pay rent in rent ledgers and bills of individual officials of the Order was a phenomenon also connected with the general crisis in the country caused by war damage. Some of the mills were abandoned at that time, others enjoyed temporary exemptions ${ }^{63}$. There was also the aforementioned practice of lowering rents in places. There is no doubt that those mills which were destroyed during the socalled "famine war" of 1414 and later during the Thirteen Years' War (1454-1466) were never rebuilt. The main reason behind this was the desolation or permanent abandonment of villages, which also resulted in the unprofitability of restoration or further use of local mills. Listing empty watermills and windmills in rent ledgers and visitations of individual commanderies constituted a sign of economic recession. Such instances were noted at the beginning of the $15^{\text {th }}$ century in the commanderies: of Gdansk/

60 Handfesten der Komturei Schlochau, bearb. v. P. Panske, Danzig 1921 no. 181 , p. 192.

61 R. Kubicki, Mtynarstwo..., p. 211.

62 "von der selbigen vnserer mole jerlich czinsen anderthalb last korns als der czins von vnserm vorfarn dem got gnode hern Johannes Reyman geryngeret was dorch beschedegunde wille des landis zo lange ab got gebe das das lant in das vorige weysen vnde statu queme ymer So sal der selbige Niclos Molner vnd seyne rechten erben vnd nachkomelynge vns vnser kirchin vnde nachfarn den alden czins als drey leste korns jerlich ausrichten”, UBP, no. 130, pp. 189-190.

63 R. Kubicki, Mtynarstwo..., p. 311. 
Ger. Danzig (there were empty mills in: Naniec (Ger. Nanitz), Pszczółki (Ger. Hohenstein), Cisowa (Ger. Ciessau), Tursiglow, Przyjaźń (Ger. Rheinfeld) and Szemud (Ger. Schönwalde); of Tuchola (Winkels mole, Ciechocin/Ger. Deutsch Cekzin, Gostycyn/Ger. Liebenau, Raciąski Młyn/Ger. Reetzer Mühle, Sławęcin/ Ger. Schlagenthin and Nowy Młyn/Ger. Neu Mühl); of Gniew/Ger. Mewe (Bobowo/Ger. Bobau and Rajkowy/Ger. Raikauer Mühle); of Grudziądz/Ger. Graudenz (Iwiczno/Ger. Iwitz); and also in the Vogtei of Dirschau (Pol. Tczew) (Trzepowo/Ger. Strippau), and in the commandery of Nieszawa/Ger. Nessau (in Wielka Nieszawka/Ger. Gross Nessau). Similarly, abandoned mills were listed in rent ledgers from 1437 in the commandery of Balga (there were empty mills in Woryny/Ger. Worienen, Deksyty/Ger. Dixen, Gelien, Kandyty/Ger. Kanditten, and Wilknity/Ger. Wilknitt). This phenomenon also occurs in rent ledgers from 1446. At that time there were three empty mills in the commandery of Brodnica (Crewtczmole, Drewantczmole, and Rawdenmole), one in the commandery of Elblag/Ger. Elbing (Panien), and two in the commandery of Pokarmin/Ger. Brandenburg (Plenitten/Rus. Ostrowskoe and Legnitten/ Rus. Proletarskoe). The very same year, a ledger referring to the commandery of Człuchów/Ger. Schlochau indicates that out of the total number of seventeen mills, as many as eight of them were empty (47\%), including one windmill (Nierybie/Ger. Peterswalder Mühle, Polnica/Ger. Polnitz, Szczytno/Ger. Ziehten, Biskupnica/ Ger. Bischofswalde, Brenszmole, Chrzęstówko/Ger. Christfelder Mühle, Prądy/Ger. Landeckermühle, Rychnowy/Ger. Richnau the windmill $)^{64}$.

As a result of the destruction of mills in the first half of the $15^{\text {th }}$ century, a considerable decline occurred in the total sum of the rent from mills which the Teutonic Order received. It amounted to $12 \%$ in the commandery of Ostróda/Ger. Osterode, $7-8 \%$ in the commandery of Balga, and $4 \%$ in the case of the commandery of Elblag/Ger. Elbing. It was much worse in the cases of the land of Kulm and Eastern Pomerania, with both lands having experienced intensive warfare, conducted during consecutive conflicts against Poland. In the commandery of Kowalewo/Ger. Schönsee,

64 GSPK, XX. HA, OBA 28953, f. 7r; R. Kubicki, Wykaz czynszów i służb komturstwa człuchowskiego $z 1446$ roku wraz z inwentarzem koni, uzbrojenia $i$ zapasów kuchni na zamku w Człuchowie, "Zapiski Historyczne” 2017, t. 82, z. 3, p. 119. 
the decrease in rent amounted to $40 \%$, in Brodnica/Ger. Strasburg to $25 \%$, and in Tuchola/Ger. Tuchel to as much as $64 \%{ }^{65}$.

When summing up the remarks above, it must be repeated that watermills and windmills were an important infrastructural element in villages and towns of the late Middle Ages. As such, they were vulnerable to destruction during military conflicts of the period. Obviously, damaging or destroying watermills and windmills also occurred as a result of natural causes: atmospheric factors (surging waters, broken dykes in the case of watermills, or strong winds when it comes to windmills). Although we do not have any registries covering the whole dominion of the Teutonic Order in Prussia, yet even on the basis of surviving accounts it may be concluded that damage inflicted during the wars the Order fought against Poland in the first half of the $15^{\text {th }}$ century resulted in a vast deterioration of economic structures in rural areas, including the watermills and windmills located there. Not all such structures were later rebuilt; most of them only remain in accounts from older rent ledgers kept by Teutonic Order officials.

65 For detailed estimates, see: J. Sarnowsky, Die Wirtschaftsführung des Deutschen Ordens..., pp. 205-206. 


\section{Annex}

\section{The number of operating and abandoned watermills and windmills in selected commanderies in the first half of the $15^{\text {th }}$ century}

\begin{tabular}{|c|c|c|c|c|c|}
\hline Commandery & Year & $\begin{array}{l}\text { Watermills/ } \\
\text { windmills } \\
\text { in total }\end{array}$ & $\begin{array}{l}\text { Including } \\
\text { empty } \\
\text { watermills/ } \\
\text { windmills }\end{array}$ & $\begin{array}{l}\% \text { of empty } \\
\text { watermills/ } \\
\text { windmills }\end{array}$ & Sources \\
\hline Bałga/Balga & 1437 & 27 & 5 & 18,5 & GZ p. 39 \\
\hline $\begin{array}{l}\text { Bałga/Balga } \\
\text { (Bartensteyn, } \\
\text { Woria, Ylaw) }\end{array}$ & 1437 & 23 & 5 & 22 & GZ p. 46 \\
\hline $\begin{array}{l}\text { Bałga/Balga } \\
\text { (waldamt } \\
\text { czum Eyns- } \\
\text { senberge) }\end{array}$ & 1437 & 12 & 1 & 8 & GZ p. 46 \\
\hline $\begin{array}{l}\text { Pokarmin/ } \\
\text { Brandenburg }\end{array}$ & 1433 & 8 & 2 & 25 & GA p. 228 \\
\hline $\begin{array}{l}\text { Pokarmin/ } \\
\text { Brandenburg }\end{array}$ & 1437 & 21 & 1 & 5 & GZ p. 53-54 \\
\hline $\begin{array}{l}\text { Brodnica/ } \\
\text { Strasburg }\end{array}$ & 1446 & 12 & 4 & 33 & $\begin{array}{c}\text { Visitationen, } \\
\text { Teil I, no. } 134 \\
\text { p. } 322\end{array}$ \\
\hline $\begin{array}{l}\text { Człuchów/ } \\
\text { Schlochau }\end{array}$ & 1413 & - & 2 & - & GA p. 653 \\
\hline $\begin{array}{l}\text { Człuchów/ } \\
\text { Schlochau }\end{array}$ & 1446 & $15 / 2$ & $7 / 1$ & 47 & $\begin{array}{c}\text { Wykaz } \\
\text { Człuchów, } \\
\text { p. } 119\end{array}$ \\
\hline $\begin{array}{l}\text { Elblag/ } \\
\text { Elbing }\end{array}$ & 1446 & 39 & 3 & 8 & $\begin{array}{l}\text { Visitationen, } \\
\text { Teil I, no. } 120 \text {, } \\
\text { p. } 246\end{array}$ \\
\hline $\begin{array}{l}\text { Elblag/ } \\
\text { Elbing }\end{array}$ & 1451 & 39 & 2 & 5 & $\begin{array}{l}\text { Visitationen, } \\
\text { Teil II no. } 176, \\
\text { p. } 148\end{array}$ \\
\hline
\end{tabular}




\begin{tabular}{|l|c|c|c|c|c|}
\hline $\begin{array}{l}\text { (Vogtei) } \\
\text { Lipienek/ } \\
\text { Leipe }\end{array}$ & 1437 & 6 & 2 & 33 & GZ p. 91 \\
\hline $\begin{array}{l}\text { Tuchola/ } \\
\text { Tuchel }\end{array}$ & 1446 & 17 & 4 & 24 & $\begin{array}{c}\text { Wykaz } \\
\text { Tuchola, } \\
\text { pp. 292-295 }\end{array}$ \\
\hline
\end{tabular}

Source: R. Kubicki, Wykaz czynszów i stużb komturstwa człuchowskiego... (hereafter: Wykaz Człuchów), p. 119; idem, Wykaz czynszowy komturstwa tucholskiego $z$ połowy XV w. (hereafter: Wykaz Tuchola), "Studia Historica Gedanensia" 2015, t. 6, pp. 292-295; Das grosse Ämterbuch des Deutschen Ordens (hereafter: GA), hrsg. v. W. Ziesemer, Danzig 1921; Das grosse Zinsbuch des Deutschen Ritterordens 1414-1438 (hereafter: GZ), hrsg. v. P.G. Thielen, Marburg 1958; Visitationen im Deutschen Orden im Mittelalter (hereafter: Visitationen), hrsg. v. M. Biskup, I. Janosz-Biskupowa, T. 1 (1236-1449), T. 2 (1450-1519), Marburg 2002-2004. (QSGDO, 50-50/II).

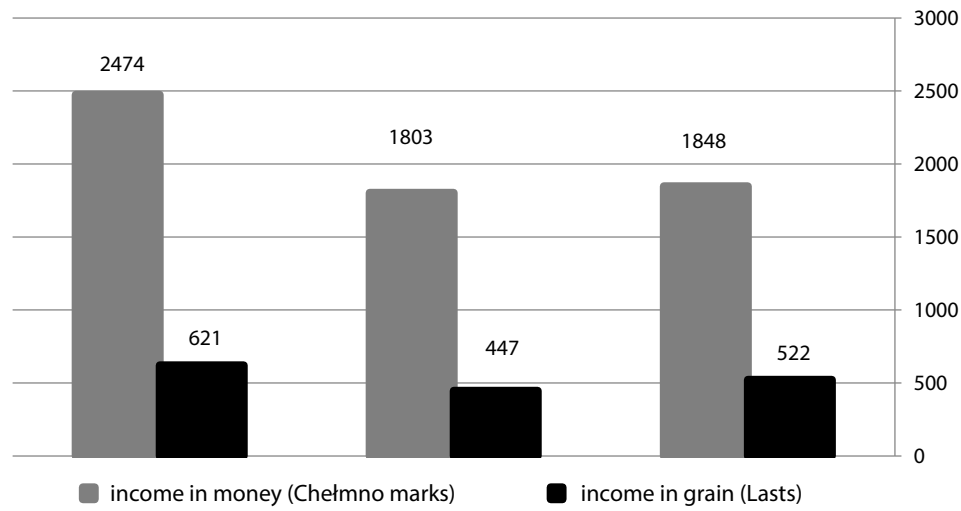

The sum of rents from mills in the years 1417-1450 (about 1417, about 1437, about 1450)

Source: Chart based on data contained in the work by J. Sarnowsky, Die Wirtschaftsführung des Deutschen Ordens..., tab. 7, p. 204. 


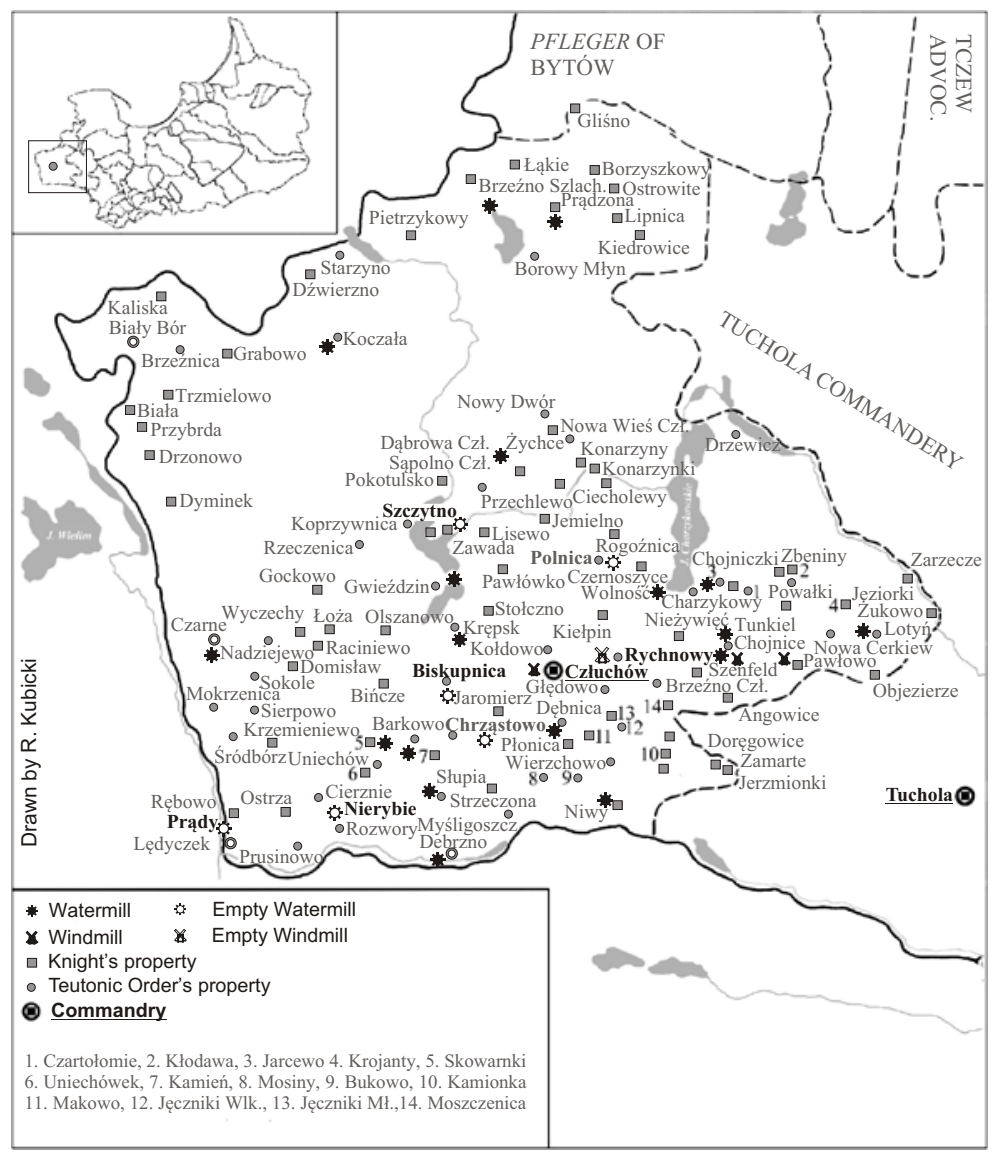

Fig. 1. Watermills and windmills in Człuchów (Ger. Schlochau) Commandry in 1446 Source: Drawn by R. Kubicki. 


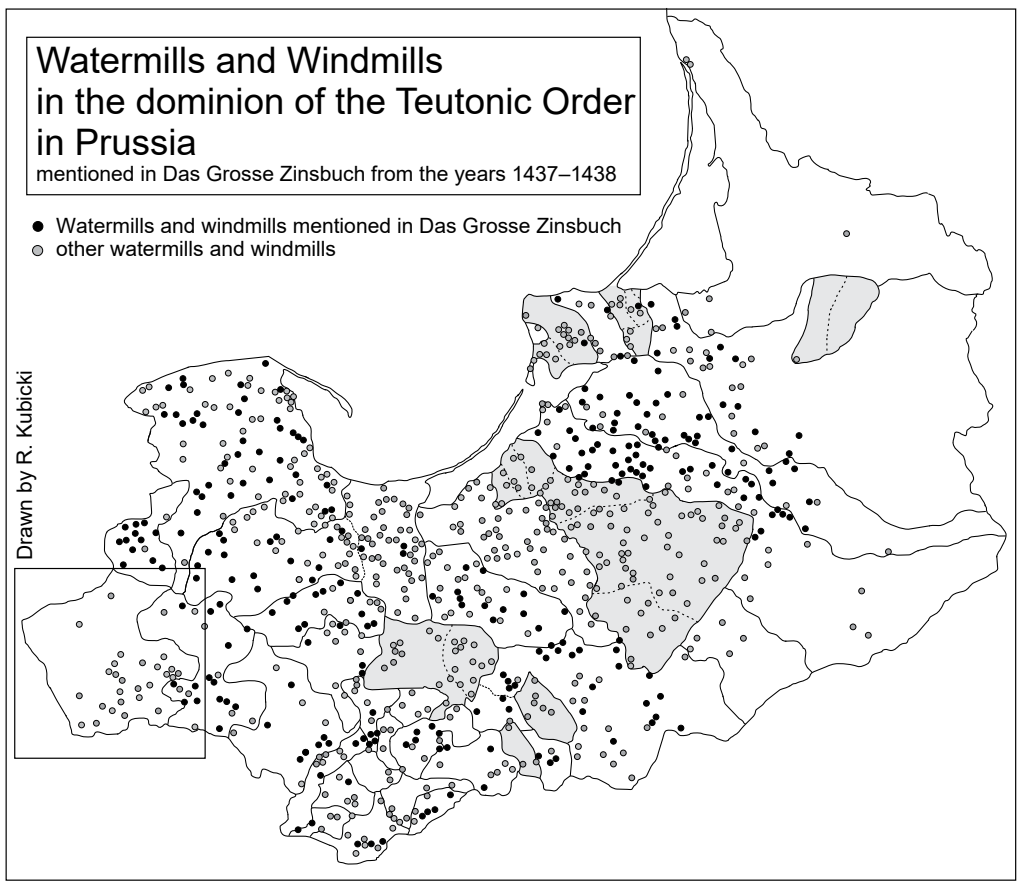

Fig. 2. Watermills and windmills in the Dominion of the Teutonic Order in Prussia mentioned in "Das Grosse Zinsbuch" from the years $1437-1438$

Source: Drawn by R. Kubicki.

\section{Streszczenie}

Uszkadzanie, niszczenie i odbudowa młynów wodnych i wiatraków w późnośredniowiecznych Prusach Zakonnych

Młyny wodne i wiatraki stanowiły ważny element infrastruktury miast i wsi w późnym średniowieczu - zapewniały bowiem możliwość przemiału odpowiedniej ilości zbóż i słodu potrzebnych do produkcji dwóch najważniejszych produktów spożywczych: chleba i piwa. $\mathrm{W}$ związku z tym były narażone na zniszczenia w czasie toczonych wówczas konfliktów zbrojnych. Oczywiście uszkodzenie i niszczenie młynów i wiatraków następowało też z przyczyn naturalnych: czynników atmosferycznych (wezbrania wody, przerwania grobli w wypadku 
młyna wodnego czy też silnego wiatru w wypadku wiatraka). Problem uszkodzenia, niszczenia, ale i odbudowy młynów wodnych i wiatraków został tu przedstawiony na przykładzie władztwa zakonu krzyżackiego w Prusach w późnym średniowieczu (w XIV i pierwszej połowie XV w.). Obok kwestii prawnych i gospodarczych związanych z tym zjawiskiem podjęto próbę określenia skali i rejonizacji występowania młynów pustych, zniszczonych lub tylko opuszczonych, uszkodzonych i później nieodbudowanych. W pierwszej połowie XV w. nastapił dość wyraźny spadek wysokości ogólnego czynszu z młynów, jaki pobierał zakon krzyżacki. Wynosił on w wypadku komturstwa ostródzkiego $12 \%$, bałgijskiego 7-8\%, a elblaskiego 4\%. Znacznie gorzej było natomiast na terenie ziemi chełmińskiej i na Pomorzu Gdańskim, które znajdowały się w zasięgu intensywnych działań wojennych, toczonych w ramach kolejnych konfliktów z Polska. W komturstwie kowalewskim spadek czynszu wyniósł $40 \%$, brodnickim $25 \%$, a w tucholskim aż $64 \%$. Wprawdzie nie dysponujemy wykazami obejmujaccymi w tym czasie całe władztwo zakonu krzyżackiego w Prusach, jednak nawet na podstawie zachowanych przekazów można stwierdzić, że działania powodowane wojnami prowadzonymi przez zakon z Polską w pierwszej połowie XV w. przyniosły ogromne zniszczenia struktur gospodarczych na wsi, w tym i znajdujących się tam młynów wodnych i wiatraków. Nie wszystkie z tych urządzeń zostały później odbudowane, po części z nich zostały jedynie wzmianki w starszych wykazach czynszowych sporządzanych przez urzędników zakonu krzyżackiego. 